\title{
Determination of the pathway for rhamnose biosynthesis in mycobacteria: cloning, sequencing and expression of the Mycobacterium tuberculosis gene encoding $\alpha$-D-glucose-1-phosphate thymidylyltransferase
}

\author{
Yufang Ma, Jonathan A. Mills, † John T. Belisle, Vara Vissa, Mark Howell, \\ Kelly Bowlin, Michael S. Scherman and Michael McNeil
}

Author for correspondence: Michael McNeil. Tel: +1970 491 1784. Fax: +1970 4911815.

e-mail : mmcneil@vines.colostate.edu

Department of Microbiology, Colorado State University, Fort Collins, Colorado 80523 , USA
The mycobacterial cell wall core consists of an outer lipid layer of mycolic acids connected, via arabinogalactan polysaccharide, to an inner peptidoglycan layer. An $\alpha$-L-rhamnopyranosyl residue has been shown to be a key component linking the mycolated arabinogalactan to the peptidoglycan and, therefore, the biosynthesis of L-rhamnose (Rha) in mycobacteria was investigated as the first step of developing inhibitors of its biosynthesis. Biochemical assays were used to show that dTDP-Rha was synthesized in Mycobacterium smegmatis from $\alpha$-D-glucose 1-phosphate ( $\alpha$-D-Glc-1-P) and dTTP by the same four enzymic steps used by Escherichia coli and other bacteria. PCR primers based on consensus regions of known sequences of the first enzyme in this series, $\alpha$-D-Glc-1-P thymidylyltransferase (RfbA) were used to amplify $r$ fbA DNA from $M$. tuberculosis. The entire IfbA gene was then cloned and sequenced. The deduced amino acid sequence revealed a 31362 Da putative protein product which showed similarity to RfbA proteins of other bacteria (59\% identity to that found in $E$. coli). Sequencing of DNA flanking the $r f b A$ gene did not reveal any of the other $\mathrm{rb}$ genes required for dTDP-Rha biosynthesis. Therefore, the four Rha biosynthetic genes are not clustered in $M$. tuberculosis. The enzymic activity of the sequenced gene product was confirmed by transformation of $E$. coli with pBluescript $\mathrm{KS}(-)$ containing the $\mathrm{ffbA}$ gene from $M$. tuberculosis. Analysis of enzyme extracts prepared from this transformant revealed an 11-fold increase in $\alpha-D-G l c-1-P$ thymidylyltransferase activity.

Keywords: rhamnose, $r f b$, mycobacterial cell wall, drug development, thymidylyltransferase

\section{INTRODUCTION}

The mycobacterial cell wall consists of a lipid mycolic acid layer (Brennan \& Nikaido, 1995; McNeil \& Brennan, 1991) attached, by means of the polysaccharide

\footnotetext{
†Present address: Chugai Biopharmaceuticals Inc., 6275 Nancy Ridge Drive, San Diego, CA 92121, USA.

Abbreviations: AG, arabinogalactan; Glc, glucose; Glc-1-P, glucose 1phosphate; Rha, rhamnose (rhamnosyl); 6-dTal, 6-deoxytalose.

The EMBL/GenBank/DDBJ accession number of the $r f b .4$ nucleotide sequence reported in this paper is U55242.
}

arabinogalactan (AG), to the peptidoglycan layer. This attachment, via $A G$, is fundamental to the structural integrity of the wall and thus required for mycobacterial viability. For example, ethambutol, which inhibits the attachment of the peptidoglycan layer to the mycolic acid layer by inhibiting the formation of the arabinan region of AG (Takayama et al., 1979; Takayama \& Kilburn, 1989; Deng et al., 1995; Mikusova et al., 1995), stops the growth of mycobacteria and is an effective drug. When AG is examined in molecular detail, it is evident that an L-rhamnosyl (L-Rha) residue plays an essential structural role as it is part of the 'linker' region, a specialized unit that links the AG proper with 


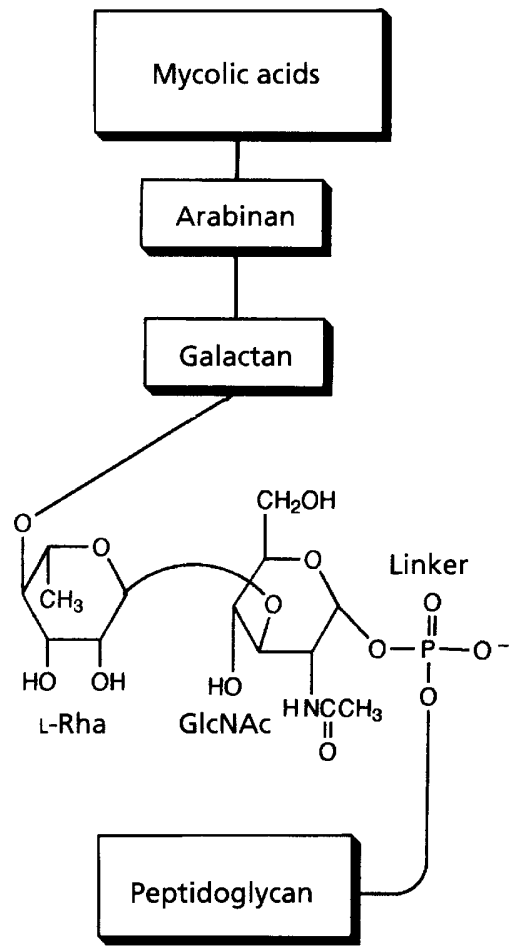

Fig. 1. Structure of the mycobacterial cell wall emphasizing the position and role of the L-Rha-containing linker disaccharide.

peptidoglycan (McNeil et al., 1990), as shown in Fig. 1. Thus, it is attractive to hypothesize that inhibition of the biosynthesis of L-Rha would be lethal to the mycobacteria by making formation of the linker unit impossible. Therefore, we have begun studies on its biosynthesis in mycobacteria.

In Gram-negative bacteria, L-Rha residues are often present in LPS and are synthesized at the sugar nucleotide level, dTDP-Rha being the nucleotide product (Shibaev, 1986). dTDP-Rha then functions as the Rha donor in all bacteria studied (Shibaev, 1986) and, indeed, in a recent report it has been shown to donate the Rha residue for the linker region in mycobacteria (Mikusova et al., 1996). The pathway for dTDP-Rha biosynthesis has been studied extensively in Gram-negative bacteria (Shibaev, 1986) and dTDP-Rha has been shown to be produced from TTP and glucose 1-phosphate (Glc-1-P) as shown in Fig. 2. The genes encoding these four biosynthetic transformations (known as $r f b A, r f b B$, $r f b C$ and $r f b D$ in Gram-negative organisms) have been cloned and sequenced in many organisms (Minnikin, 1982; Stevenson et al., 1994; Rajakumar et al., 1994). They have invariably been found in a biosynthetic operon with the genes usually in the order $r f b B D A C$ (Stevenson et al., 1994).

Here we present evidence that mycobacteria produce dTDP-Rha by the same sequence of reactions shown in Fig. 2. We also report the cloning, sequencing and expression in Escherichia coli, of the first of the

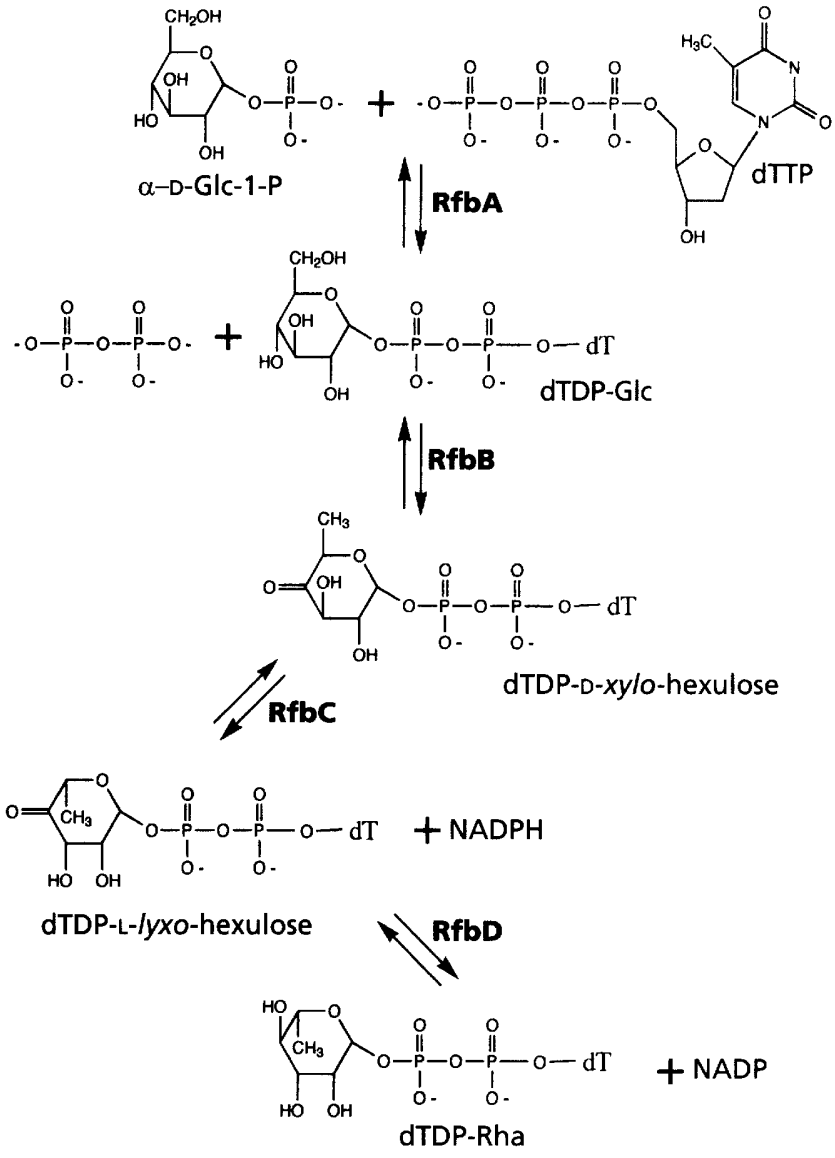

Fig. 2. The biosynthetic pathway for formation of dTDP-Rha as found in Gram-negative bacteria and, as shown here, in mycobacteria. RfbA, $\alpha$-D-Glc-1-P thymidylyltransferase; RfbB, dTDP-Glc 4,6-dehydratase; RfbC, dTDP-6-deoxy-4-ketoglucose epimerase; RfbD, dTDP-Rha synthase.

Mycobacterium tuberculosis Rha biosynthetic genes, namely the $r f b A$ gene which encodes $\alpha$-D-Glc-1-P thymidylyltransferase (RfbA). Sequence data in the vicinity of $r f b A$ show that, in contrast to Gram-negative organisms, the $r f b A$ gene is not clustered with the remaining $\mathrm{Rha}$ genes.

\section{METHODS}

Chemicals, biochemicals and enzymes. All chemicals, enzymes and biochemicals were purchased from Sigma unless otherwise indicated. dTDP-[U- $\left.-{ }^{14} \mathrm{C}\right]$ glucose (dTDP- $\left[{ }^{14} \mathrm{C}\right] \mathrm{Glc}$ ), specific activity $257 \mathrm{mCi} \mathrm{mmol}^{-1}\left(9.5 \times 10^{9} \mathrm{~Bq} \mathrm{mmol}^{-1}\right)$, was purchased from ICN and is unfortunately no longer available. Restriction enzymes were obtained from Boehringer Mannheim and used according to the supplier's instructions.

Bacterial strains and plasmids. The bacterial strains and plasmids used in this study are described in Table 1. $M$. smegmatis ATCC 8548 and $M$. tuberculosis H37Rv were grown on glycerol-alanine-salts medium (Takayama et al., 1975). E. coli DH5 $\alpha$ and $S \phi 874$ were grown on LB medium (Life Technologies). When necessary, antibiotics were used at 
dTDP-rhamnose biosynthesis in mycobacteria

Table 1. Properties and sources of relevant bacterial strains and plasmids

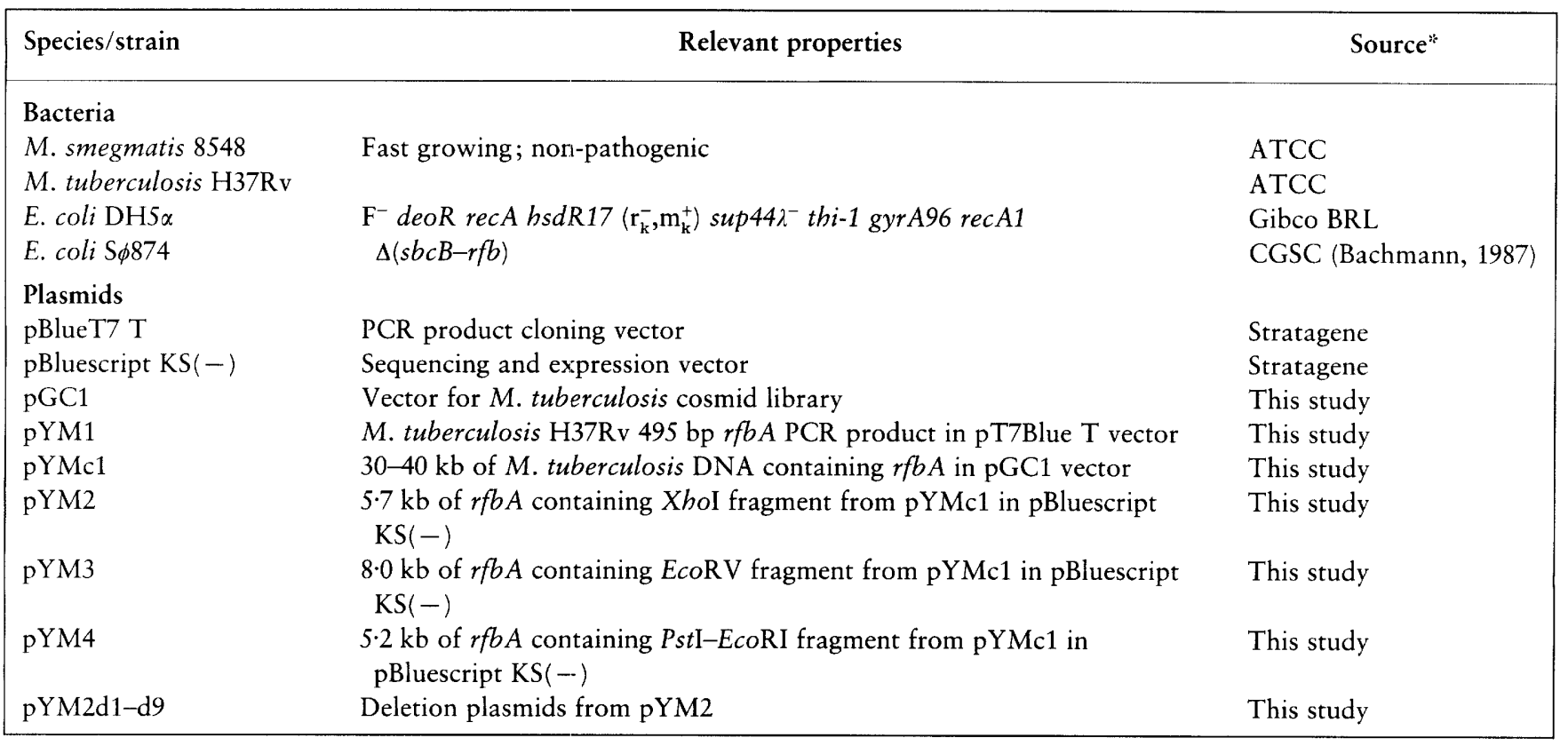

*ATCC, American Type Culture Collection, Rockville, MD, USA; CGSC, E. coli Genetic Stock Center, Yale University, New Haven, Connecticut, USA.

the following final concentrations: ampicillin, $50 \mu \mathrm{g} \mathrm{ml}^{-1}$; kanamycin, $30 \mu \mathrm{g} \mathrm{ml}^{-1}$; tetracycline, $12 \cdot 5 \mu \mathrm{g} \mathrm{ml}^{-1}$.

Cell-free assays using $\boldsymbol{M}$. smegmatis. M. smegmatis ATCC 8548 was prepared as a cell-free extract by sonicating the cells at $4{ }^{\circ} \mathrm{C}$ with a 4710 series Cole Parmer Ultrasonic homogenizer in a buffer solution containing $50 \mathrm{mM}$ HEPES, $\mathrm{pH} 7 \cdot 6,10 \mathrm{mM}$ $\mathrm{MgCl}_{2}, 5 \mathrm{mM} \mathrm{MnCl}, 0 \cdot 2 \mathrm{mM}$ PMSF and $1 \mathrm{mM}$ DTT. The cell homogenate was then centrifuged at $12000 \mathrm{~g}$ for $10 \mathrm{~min}$ and the protein concentration of the resulting supernatant was measured using the Bio-Rad Protein Assay.

To assay for RfbA activity, $0.5 \mu \mathrm{Ci}\left(1.85 \times 10^{4} \mathrm{~Bq}\right)$ dTDP$\left[{ }^{14} \mathrm{C}\right]$ Glc was incubated in a total volume of $110 \mu \mathrm{l}$, with the final concentrations of reagents as follows: cold dTDP-Glc, $0.1 \mathrm{mM} ; \mathrm{MgCl}_{2}, 5 \mathrm{mM}$; NaF, $5 \mathrm{mM}$; tetrasodium pyrophosphate, $1 \mathrm{mM}$; crude $M$. smegmatis protein extract, $0.5 \mathrm{mg} \mathrm{ml}^{-1}$. The sample was incubated for $45 \mathrm{~min}$ at $30^{\circ} \mathrm{C}$ and then injected onto an HPLC system consisting of a $4 \times 250 \mathrm{~mm}$ Partisil 10-SAX anion exchange HPLC column (Whatmann). The sample was eluted with a gradient of $\mathrm{NH}_{4} \mathrm{H}_{2} \mathrm{PO}_{4}$ from 5 to $185 \mathrm{mM}$ over a period of $75 \mathrm{~min}$ with a flow rate of $1 \mathrm{ml} \mathrm{min}{ }^{-1}$. Seventy $1 \mathrm{ml}$ fractions were then counted for radioactivity using liquid scintillation. A control reaction was run in the same fashion except the $\mathrm{PP}_{1}$ and $\mathrm{NaF}$ were omitted.

The assay for RfbB activity was performed as described by Wang \& Gabriel (1969) except for the use of $50 \mathrm{mM}$ HEPES, $\mathrm{pH} 7 \cdot 6$, instead of Tris buffer.

The assay for the combination of $\mathrm{RfbB}, \mathrm{RfbC}$ and $\mathrm{RfbD}$ enzymes was done in a $100 \mu \mathrm{l}$ volume and the final concentrations of reagents were as follows: dTDP- $\left[{ }^{14} \mathrm{C}\right] \mathrm{Glc}, 0.5 \mu \mathrm{Ci}$ $\left(1.85 \times 10^{4} \mathrm{~Bq}\right)$; cold dTDP-Glc, $0.5 \mathrm{mM}$; NADPH, $10 \mathrm{mM}$; $\mathrm{NAD}^{+}, 5 \mathrm{mM} ; \mathrm{M}$. smegmatis enzyme extract prepared as described above, $7.5 \mathrm{mg}$ protein $\mathrm{ml}^{-1}$. The tube was incubated for $45 \mathrm{~min}$ at $30^{\circ} \mathrm{C}$ and was made $50 \%$ with respect to ethanol resulting in a soluble crude sugar nucleotide fraction. After centrifugation at $12000 \mathrm{~g}$ for $5 \mathrm{~min}$, the clear supernatant was dried, hydrolysed with $2 \mathrm{M}$ trifluoroacetic acid for $1 \mathrm{~h}$ at $120^{\circ} \mathrm{C}$ and dried. The hydrolysate was then injected onto a Dionex HPLC System with a Dionex Carbopak PA1 column $(4 \times 250 \mathrm{~mm})$ with isocratic elution with $10 \mathrm{mM} \mathrm{NaOH}$. Thirty $1 \mathrm{ml}$ fractions were then counted for radioactivity in a liquid scintillation system.

DNA techniques. M. tuberculosis DNA was prepared using the protocol described for M. avium (Belisle et al., 1991). DNA was isolated from agarose gels with a Geneclean II kit (Bio101). Purified plasmids were prepared using a QIAGEN plasmid kit according to the manufacturer's instructions.

PCR and sequencing of PCR products. Amino acid sequence alignment of known bacterial $\alpha$-D-Glc-1-P thymidylyltransferases [Shigella flexneri (Rajakumar et al., 1994), E. coli (Stevenson et al., 1994), Yersinia enterocolitica (Zhang et al., 1993) and Streptomyces griseus (Distler et al., 1987)] revealed highly conserved sequences. Two degenerated primers were designed based on the conserved TRLYPIT and AVTGLYFY stretches shown in Figs 6 and 7, and the M. tuberculosis codon usage preference (Hatfull \& Sarkis, 1993). The sense primer was $5^{\prime} \mathrm{AC}(\mathrm{GC}) \mathrm{CG}(\mathrm{GC}) \mathrm{CT}(\mathrm{GC}) \mathrm{TACCC}(\mathrm{GC}) \mathrm{ATCAC} 3^{\prime}$ and the antisense primer was $5^{\prime}$ GTAGAAGTA(GC)AG(AGCT)$\mathrm{CC}(\mathrm{GC}) \mathrm{GT}(\mathrm{GC}) \mathrm{AC}(\mathrm{GC}) \mathrm{GC} 3^{\prime}$. PCR was performed in a total volume of $50 \mu \mathrm{l}$ using a Thermal Cycler (Perkin Elmer). The reaction mixture contained 1.25 units AmpliTaq DNA polymerase (Perkin Elmer), buffer $(10 \mathrm{mM}$ Tris/ $\mathrm{HCl}, \mathrm{pH} 8 \cdot 3$, $50 \mathrm{mM} \mathrm{KCl}, 2.5 \mathrm{mM} \mathrm{MgCl}{ }_{2}$ ), $0.2 \mathrm{mM}$ each deoxynucleotide triphosphate (Gibco BRL), 10 pmol each primer and 0.4-1.0 $\mu \mathrm{g}$ M. tuberculosis H37Rv genomic DNA. The PCR conditions consisted of 1 cycle of denaturation $\left(94^{\circ} \mathrm{C}, 5 \mathrm{~min}\right)$ followed by 35 cycles of amplification consisting of denaturation $\left(94^{\circ} \mathrm{C}\right.$, $1 \mathrm{~min}$ ), annealing $\left(65^{\circ} \mathrm{C}, 1 \mathrm{~min}\right)$ and primer extension $\left(72^{\circ} \mathrm{C}\right.$, $1 \mathrm{~min})$. After the final cycle there was a 7 min incubation at $72{ }^{\circ} \mathrm{C}$. A PCR product of correct size (495 bp) was cloned into the pBlueT7 T vector (Stratagene) resulting in plasmid pYM1. 
The cloned PCR product was sequenced using the Sequenase Version 2.0 DNA Sequencing Kit (USB). The BLAST algorithm was used to search protein databases for similarity (Altschul $e t$ al., 1990).

DNA probe preparation and DNA hybridization. A 546 bp $X b a \mathrm{I}-E c o R I$ restriction fragment (containing the entire $r f b A$ PCR product and a small amount of DNA on each end from the pBlueT7 $\mathrm{T}$ vector) from pYM1 was prepared and a digoxigenin non-radioactive probe made from it using a DNA labelling kit, Genius 2 (Boehringer Mannheim). For Southern blotting, $1 \mu \mathrm{g}$ M. tuberculosis H37Rv genomic DNA was digested with 10 units BamHI, ClaI, EcoRI, EcoRV, PstI and $X$ hoI, respectively, and separated by electrophoresis through a $0.7 \%$ agarose gel. The gel was treated for $10 \mathrm{~min}$ with $0.25 \mathrm{M}$ $\mathrm{HCl}$ and then for $30 \mathrm{~min}$ with $0.6 \mathrm{M} \mathrm{NaCl} / 0.4 \mathrm{M} \mathrm{NaOH}$. DNA was transferred to a Maximum Strength Nytran Plus membrane (Schleicher \& Schuell) and immobilized by UV cross-linking. The membrane was pre-hybridized at $42^{\circ} \mathrm{C}$ for $2 \mathrm{~h}$ in pre-hybridization buffer containing $5 \times \mathrm{SSC}(1 \times \mathrm{SSC}$ is $0.15 \mathrm{M}$ sodium chloride, $0.015 \mathrm{M}$ sodium citrate), $0.1 \% \mathrm{~N}$ lauroylsarcosine, $0.02 \%$ SDS, $1 \%$ blocking reagent (Boehringer Mannheim) and 50\% deionized formamide. Following this treatment, the digoxigenin-labelled $546 \mathrm{bp}$ $X b a \mathrm{I}-E c o \mathrm{RI} r f b A$ probe was denatured, added to the membrane and incubated at $42{ }^{\circ} \mathrm{C}$ overnight. The membrane was washed three times at room temperature with $2 \times \mathrm{SSC} / 0 \cdot 1 \%$ SDS and then twice at $65{ }^{\circ} \mathrm{C}$ with $0.5 \times$ SSC $/ 0.1 \%$ SDS. Colorimetric detection was carried out using a nucleic acid detection kit, Genius 3 (Boehringer Mannheim).

Construction and screening of a cosmid library. A cosmid library of $M$. tuberculosis genomic DNA was constructed in pGC1, an E. coli-Mycobacterium shuttle cosmid. For this study, pGC1-based cosmid clones were used merely as a $M$. tuberculosis H37Rv DNA library source and the shuttle properties of the cosmid were not utilized. Vector pGC1 was constructed by ligation of a 2044 bp BamHI-PstI fragment containing $\lambda \cos$ from pYUB18 (Belisle et al., 1991) with pEP2 (Radford \& Hodgson, 1991) digested with BamHI-PstI. The M. tuberculosis cosmid library was constructed with $30-40 \mathrm{~kb}$ fragments generated by a partial Sau3A digestion of $M$. tuberculosis DNA followed by ligation to BamHI-digested pGC1. The ligation mixture was packaged in vitro with Gigapack II XL Packaging Extracts (Stratagene) and transduced into DH $5 \alpha$ cells (Gibco BRL). To locate cosmids containing $r f b A, E$. coli recombinant colonies were lifted onto Optitran membranes (Schleicher \& Schuell), lysed and then hybridized with the $546 \mathrm{bp} \mathrm{XbaI-EcoRI} \mathrm{probe} \mathrm{(Maniatis} \mathrm{et}$ al., 1982).

Southern analysis of five positive cosmid clones digested with a variety of restriction enzymes and probed with the $546 \mathrm{bp}$ $X b a \mathrm{I}-E c o \mathrm{RI} r f b A$ DNA probe yielded blots identical to those prepared with genomic DNA. Therefore, one of the five cosmid clones, pYMc1, was used to subclone smaller fragments containing $r f b A$. Thus, $5.7 \mathrm{~kb}$ Xhol, $8 \mathrm{~kb} E c o \mathrm{RV}$ and $5 \cdot 2 \mathrm{~kb}$ EcoRI-Pst I fragments were prepared from pYMc1 and individually subcloned into pBluescript II KS $(-$ ) (Stratagene) to produce pYM2, pYM3 and pYM4, respectively.

DNA sequencing and analysis. Sequences of double-stranded plasmid DNA were determined using the Taq FS Ready Reaction Kit (Applied Biosystems) on a GeneAmp PCR system 9600 (Perkin Elmer) and run on an ABI 377 PRISM Sequencer (Applied Biosystems) at the Macromolecular Resource Facility at Colorado State University, USA. To sequence $r f b A$, plasmids pYM2, pYM3, pYM4 and pYMc1 were all used as sources of template DNA. Initial sequencing was done using the PCR primers as primers. Additional primers were then synthesized as needed using newly obtained sequence data. Both strands of the $r f b A$ DNA were fully sequenced and these two sequences were in complete agreement. Comparisons of sequences with the database were done using the BLAST program (Altschul et al., 1990).

To sequence the $5^{\prime}$ and $3^{\prime}$ flanking regions of $r f b A$, the nested deletion sequencing method was used. Thus, the pYM2 plasmid was digested with $S a c \mathrm{I}$ and $\mathrm{XbaI}$. The resulting linear DNA was deleted using the Erase-a-Base System (Promega). The fragments resulting from nine different digestion times were re-circularized to form plasmids pYM2d1-9. These cosmids were sequenced as above using a primer based on the $\mathrm{M} 13(-20)$ site present on the pBluescript II $\mathrm{KS}(-)$ vector. pYM2d1 was deleted such that sequencing commenced approximately $2 \mathrm{~kb}$ downstream from the $3^{\prime}$ end of $r f b A$, pYM2d9 was situated so that sequencing began approximately $2 \mathrm{~kb}$ upstream from the $5^{\prime}$ end of $r f b A$ and the sequencing commenced on the remaining plasmids in between these two extremes. For these experiments only a single strand of DNA was sequenced and the sequences were then subjected to BLAST searches. The sequence of $r f b A$ itself was found in pYM $2 \mathrm{~d} 5$ and pYM2d 6 but no sequence corresponding to any other $r f b$ genes was obtained.

Expression of $\alpha$-D-GlC-1-P thymidylyltransferase in $E$. coli and measurement of its activity. E. coli $\mathrm{S} \phi 874$ was transformed with pYM2 and with pBluescript II KS(-) only, as a control. Single colonies of each transformant were grown in $10 \mathrm{ml} \mathrm{LB}$ broth with ampicillin. The resulting cultures were transferred into 1 litre of the same medium and grown to an $\mathrm{OD}_{600}$ of 0.6 after which IPTG was added to a final concentration of $1 \mathrm{mM}$. Cells were harvested after an additional $3 \mathrm{~h}$ of incubation. One half gram of each of the transformed cell preparations was resuspended in $1 \mathrm{ml}$ breaking buffer $(0 \cdot 1 \mathrm{mM}$ PMSF, $1 \mathrm{mM}$ DTT, $50 \mathrm{mM}$ HEPES, pH 7.4), sonicated with a 4710 series Cole Palmer ultrasonics homogenizer and centrifuged for $20 \mathrm{~min}$ at $16000 \mathrm{~g}$. The protein concentration of the supernatants containing the crude enzyme was determined using the Bio-Rad Protein Assay.

The crude enzymes prepared from the two E. coli strains were then assayed for $\alpha$-D-Glc-1-P thymidylyltransferase activity. The assay was based on the formation of Glc-1-P as described for the $M$. smegmatis enzyme; however, the Glc-1-P was detected by a linked enzyme assay which produced NADPH rather than by HPLC. The enzyme assays were done in a volume of $1 \mathrm{ml}$ containing $184 \mathrm{mM}$ HEPES, pH 7.4, $4 \mathrm{mM}$ tetrasodium pyrophosphate, $5 \mathrm{mM} \mathrm{MgCl}_{2}, 2 \mathrm{mM}$ NADP, $1 \mathrm{mM}$ TDP-Glc (or $1 \mathrm{mM}$ UDP-Glc to determine $\alpha$-D-Glc-1-P uridylyltransferase activity), $0.02 \mathrm{mM}$ Glc 1,6-diphosphate, 0.2 units phosphoglucomutase, 1 unit Glc-6-P dehydrogenase and $148 \mu \mathrm{g}$ crude enzyme. The rate of formation of NADPH was determined spectrophotometrically at $340 \mathrm{~nm}$. A parallel reaction was done in the absence of $\mathrm{PP}_{i}$.

\section{RESULTS}

\section{Demonstration of RfbA, B, C and D activities in mycobacteria}

We have previously shown that the cell wall core of $M$. tuberculosis and $M$. smegmatis contain the same linker disaccharide (Fig. 1) and that the arabinosyl and galactosyl residues of their respective AGs are arranged identically as determined by ${ }^{1} \mathrm{H}$ and ${ }^{13} \mathrm{C}$ NMR analyses (Daffé et al., 1993). Therefore, it is highly likely that the 

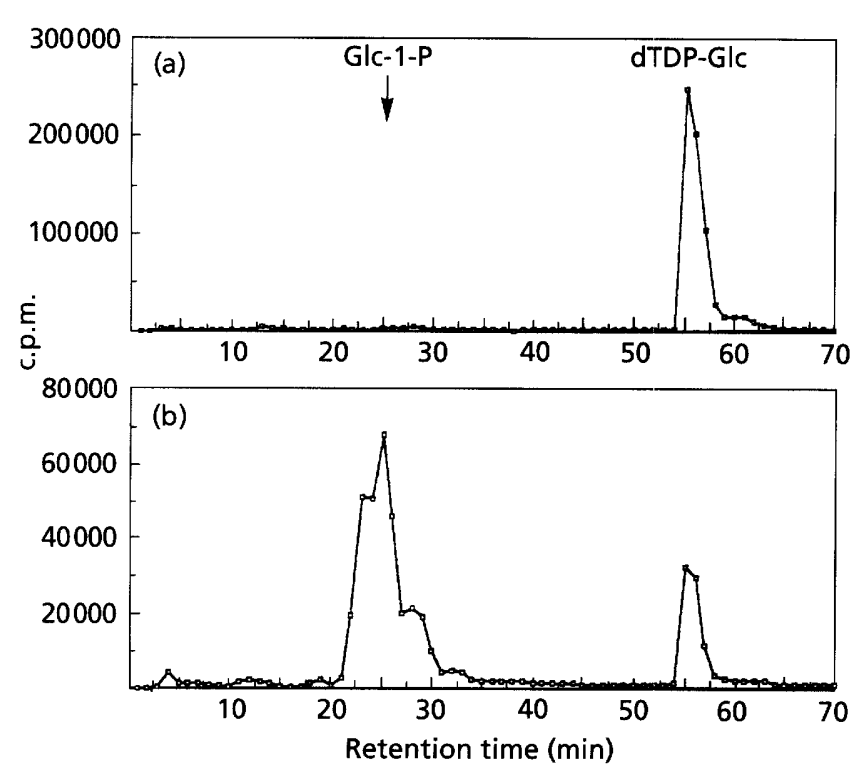

Fig. 3. Inorganic $\mathrm{PP}_{\mathrm{i}}$-dependent conversion of dTDP-[$\left[{ }^{14} \mathrm{C}\right] \mathrm{Glc}$ to $\alpha$-D-GlC-1-P by $\alpha$-D-GlC-1-P thymidylyltransferase present in enzyme extracts of $M$. smegmatis. HPLC profiles of reaction products from dTDP- $\left[{ }^{14} \mathrm{C}\right] \mathrm{Glc}$ and enzyme extract without (a) and with (b) added $\mathrm{PP}_{\mathrm{i}}$. Authentic $\alpha$-Glc-1-P eluted in $25 \mathrm{~min}$ under the conditions used; the heterogeneity seen around $25 \mathrm{~min}$ in (b) probably results from further conversion of Glc-1-P into other sugar phosphates.

cell wall cores, including the Rha residues, are synthesized in the same fashion in both species. We therefore decided for practical reasons to conduct biosynthetic assays using extracts from the fast-growing and non-pathogenic $M$. smegmatis but, since our ultimate aim is to design new drugs against tuberculosis, we conducted cloning experiments using $M$. tuberculosis DNA. Thus, we first looked for the presence $\alpha$-D-Glc-1$\mathrm{P}$ thymidylyltransferase ( $\mathrm{RfbA}$ ) activity in a crude extract of $M$. smegmatis utilizing the reverse direction reaction (see Fig. 2). dTDP- $\left[{ }^{14} \mathrm{C}\right] \mathrm{Glc}$ was incubated with $M$. smegmatis enzyme extracts in the absence and presence of $\mathrm{PP}_{\mathrm{i}}$ as this is needed as a co-substrate for the reaction. HPLC analysis of the products showed that in the absence of $\mathrm{PP}_{i}$ (Fig. 3a) no reverse reaction forming Glc-1-P took place. However, when $\mathrm{PP}_{\mathrm{i}}$ was added to this system (Fig. 3b), dTDP-Glc was cleaved to yield TTP (data not shown) and radioactive Glc-1-P (Fig. 3b).

dTDP-Glc 4,6-dehydratase (RfbB) was assayed spectrophotometrically (Wang \& Gabriel, 1969) as the product of dTDP-Glc dehydrogenase, dTDP-6-deoxy-4ketoglucose, yields an UV-active compound after treatment with base. Incubation of varying amounts of crude enzyme prepared from $M$. smegmatis with dTDP-Glc followed by base treatment gave $A_{318}$ values that were fourfold greater than those of controls with no dTDPGlc in the incubation. At a protein concentration of $70 \mu \mathrm{g} \mathrm{ml}^{-1}$ the $M$. smegmatis enzymes converted $97 \mathrm{nmol}$ dTDP-Glc to dTDP-6-deoxy-4-ketoglucose $\min ^{-1}(\text { mg protein })^{-1}$.

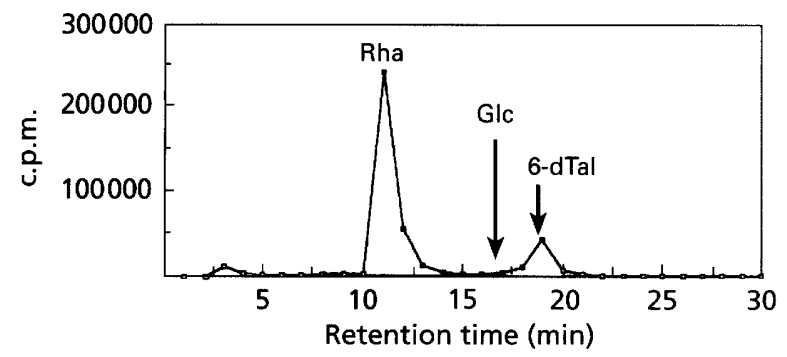

Fig. 4. Conversion of $d T D P-\left[{ }^{14} \mathrm{C}\right] \mathrm{Glc}$ to $\left[{ }^{14} \mathrm{C}\right] \mathrm{Rh}$ a by treatment with an enzyme extract of $M$. smegmatis followed by acid hydrolysis. HPLC analysis of the resultant sugars is presented. Most of the radioactive Glc was converted to Rha with a small amount being converted to 6-dTal. The elution positions of all three sugars (determined using standards) are indicated.

RfbB activity was confirmed and evidence for the activities of dTDP-6-deoxy-4-ketoglucose epimerase (RfbC) and dTDP-Rha synthase (RfbD) obtained by the conversion of dTDP-Glc to a Rha-yielding product (presumably dTDP-Rha). Thus dTDP- $\left[{ }^{14} \mathrm{C}\right]$ Glc was treated with a $M$. smegmatis enzyme extract, the resultant sugar nucleotides hydrolysed and the free sugars analysed by Dionex anion exchange chromatography (Fig. 4). The results demonstrated the enzymic conversion of the Glc unit to Rha with a small amount of Glc being converted to 6-deoxytalose (6-dTal) (see Discussion).

\section{Amplification, cloning and sequencing of $r b A$ DNA from $M$. tuberculosis}

The $\alpha$-D-Glc-1-P thymidylyltransferase amino acid sequences from Sh. flexneri (Rajakumar et al., 1994), E. coli (Stevenson et al., 1994), Y. enterocolitica (Zhang et al., 1993) and S. griseus (Distler et al., 1987) were aligned. PCR primers were designed based on sequence similarities, mycobacterial codon bias and melting temperatures (see Fig. 6 for primer positions). Using $M$. tuberculosis $\mathrm{H} 37 \mathrm{Rv}$ DNA as a template, a PCR product of the correct size was amplified. The PCR product was cloned into pT7Blue $T$ vector (see Table 1), resulting in pYM1, and a partial sequence determined. A BLAST search (Altschul et al., 1990) showed significant homology with $r f b A$ from several species. Analyses by Southern blotting of genomic M. tuberculosis DNA cut with various restriction enzymes using a $546 \mathrm{bp}$ probe containing $r f b A$ sequence generated from pYM1 all yielded single bands (Fig. 5), suggesting that only a single copy of the gene is present in the M. tuberculosis genome.

To isolate the entire $r f b A$ gene, the 546 bp $r f b A$ probe was used to screen the $M$. tuberculosis:pGC1 cosmid library by colony blot hybridization. A cosmid, pYMc1, obtained from a positive colony was subsequently analysed by Southern blot analysis with the same probe. The hybridization pattern was identical to that shown in Fig. 5 for genomic DNA as expected. Thus, three 


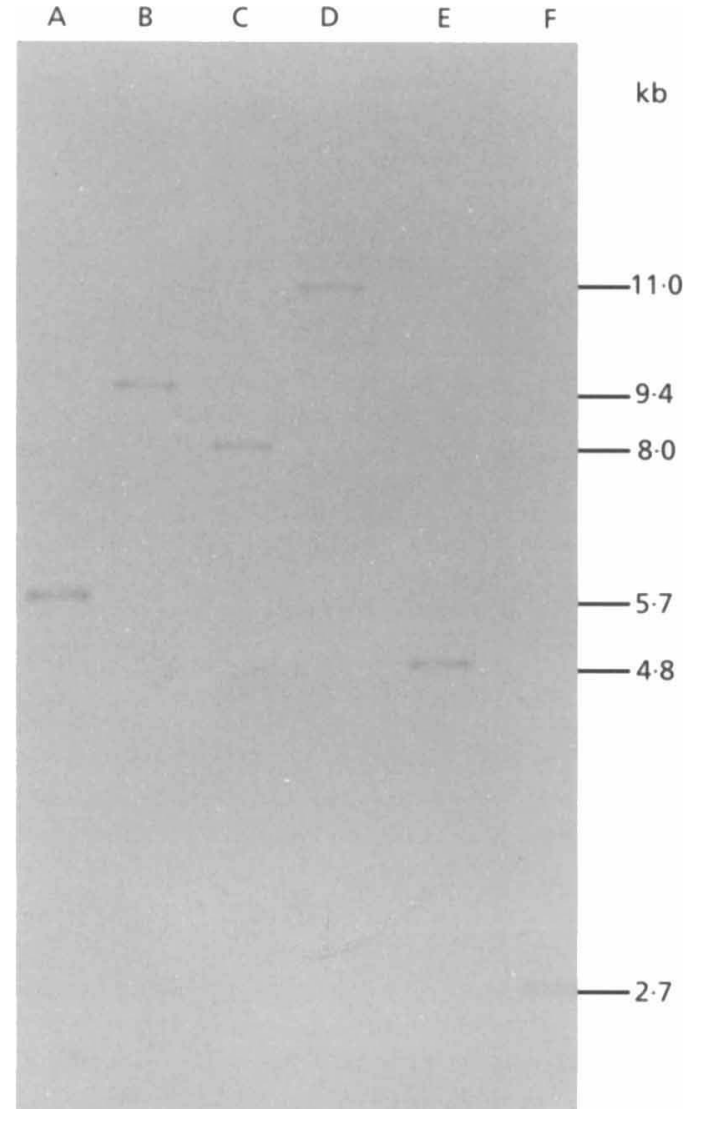

Fig. 5. Southern blot analysis of $M$. tuberculosis DNA digested with various enzymes and hybridized with the rfbA $546 \mathrm{bp}$ probe. Lanes: A, Xhol; B, Pstl; C, EcoRV; D, EcoRI; E, Clal; F, BamHI.

subclones, pYM2, pYM3 and pYM4, were prepared from pYMc1 by ligation of its $5.7 \mathrm{~kb} X h o \mathrm{I}, 8.0 \mathrm{~kb}$ EcoRV and $5 \cdot 2$ Pst $\mathrm{I}-E c o$ RI restriction fragments, respectively, into pBluescript II KS(-) (Table 1).

The complete sequence of $r f b A$ was then obtained using plasmids pYMc1, pYM2, pYM3 and pYM4 as templates for double-stranded automated sequencing. The sequence is presented in Fig. 6 . The $\mathrm{G}+\mathrm{C}$ content was found to be $61 \%$ and a putative ribosome binding site was detected. The DNA encoded a protein of 288 aa with a molecular mass of $31362 \mathrm{kDa}$. The deduced amino acid sequence is compared with $\alpha$-D-Glc-1-P thymidylyltransferase amino acid sequences from other Gram-negative bacteria and one Gram-positive bacterium in Fig. 7 . In addition, the sequence flanking the $r f b A$ gene present in the pYM2 subclone was obtained by the nested deletion method. Approximately $2 \mathrm{~kb}$ on each side of $r f b A$ were sequenced. BLAST searches of these sequences resulted in the recognition of no other genes except $r f b A$; it was expected that the other $r f b$ genes should have readily been detected if they flanked $r f b A$ as in other bacteria.

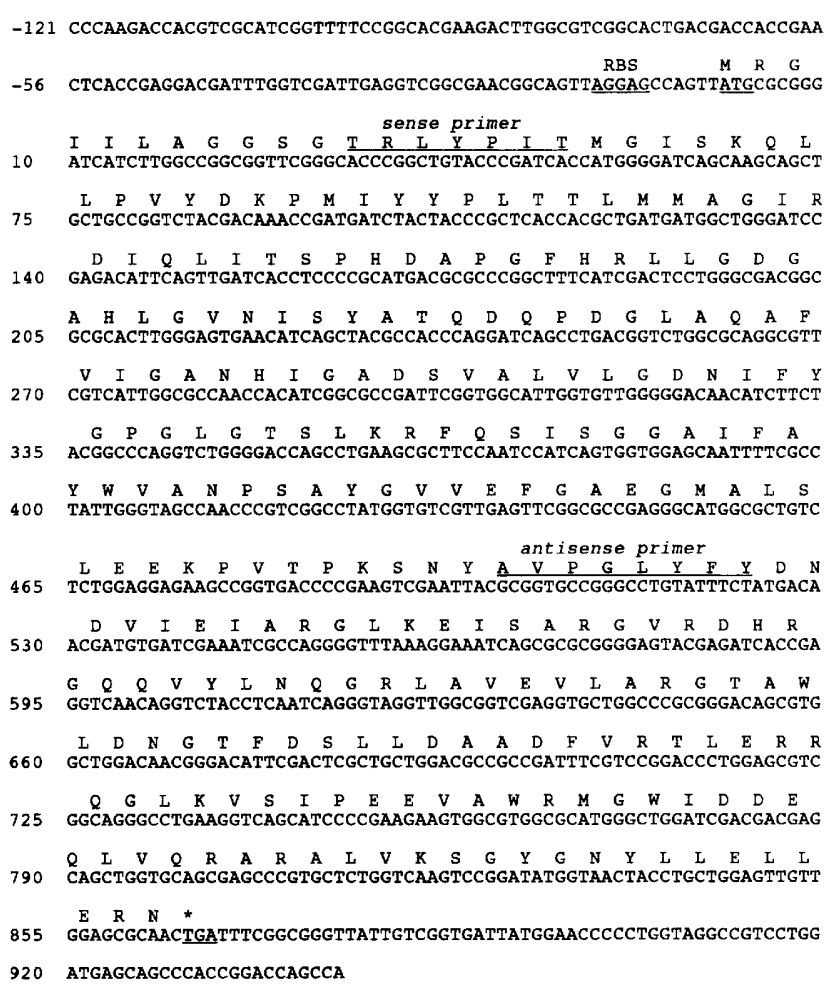

Fig. 6. DNA sequence and deduced amino acid sequence of $M$. tuberculosis $r \mathrm{fb} A$ encoding $\alpha-\mathrm{D}-\mathrm{Gl}$ - $-1-\mathrm{P}$ thymidylyltransferase. The start codon (ATG), putative ribosome binding site (RBS), location of the PCR primers and stop codon $\left({ }^{*}\right)$ are indicated.

\section{Expression of $r \mathrm{fbA}$}

E. coli strain $\mathrm{S} \phi 874$, a strain where the entire $r f b$ region is deleted, was chosen to express the $M$. tuberculosis $r f b A$ gene. It was recognized that this strain would express low levels of $\alpha$-D-Glc-1-P thymidylyltransferase activity due to the presence of a functional homologue of rfbA (Marolda \& Valvano, 1995), but it was expected that this background level of activity would still be considerably less than that of a wild-type E. coli. Thus, E. coli $\mathrm{S} \phi 874$ was transformed with pYM2 and, as a control, with pBluescript $\mathrm{KS}(-)$ vector only. The transformants were grown to mid-exponential phase, treated with IPTG, harvested, disrupted by sonication, centrifuged and enzyme assays for Glc-1-P thymidylyltransferase (RfbA) and Glc-1-P uridylyltransferase were conducted. As expected, the control bacteria showed some Glc-1-P thymidylyltransferase activity (Table 2). However, bacteria containing the Xhol subclone showed an approximately 11 -fold elevation of Glc-1-P thymidylyltransferase activity per $\mathrm{mg}$ protein.

\section{DISCUSSION}

The results of the biochemical studies strongly suggest that dTDP-Rha is formed by the same pathway in mycobacteria as it is in other bacteria (Fig. 2). In addition, the biosynthesis of $6-\mathrm{dTal}$ was also shown to occur in $M$. smegmatis (Fig. 4) by use of RfbA-C followed by reduction of the keto sugar (Fig. 2) by the 


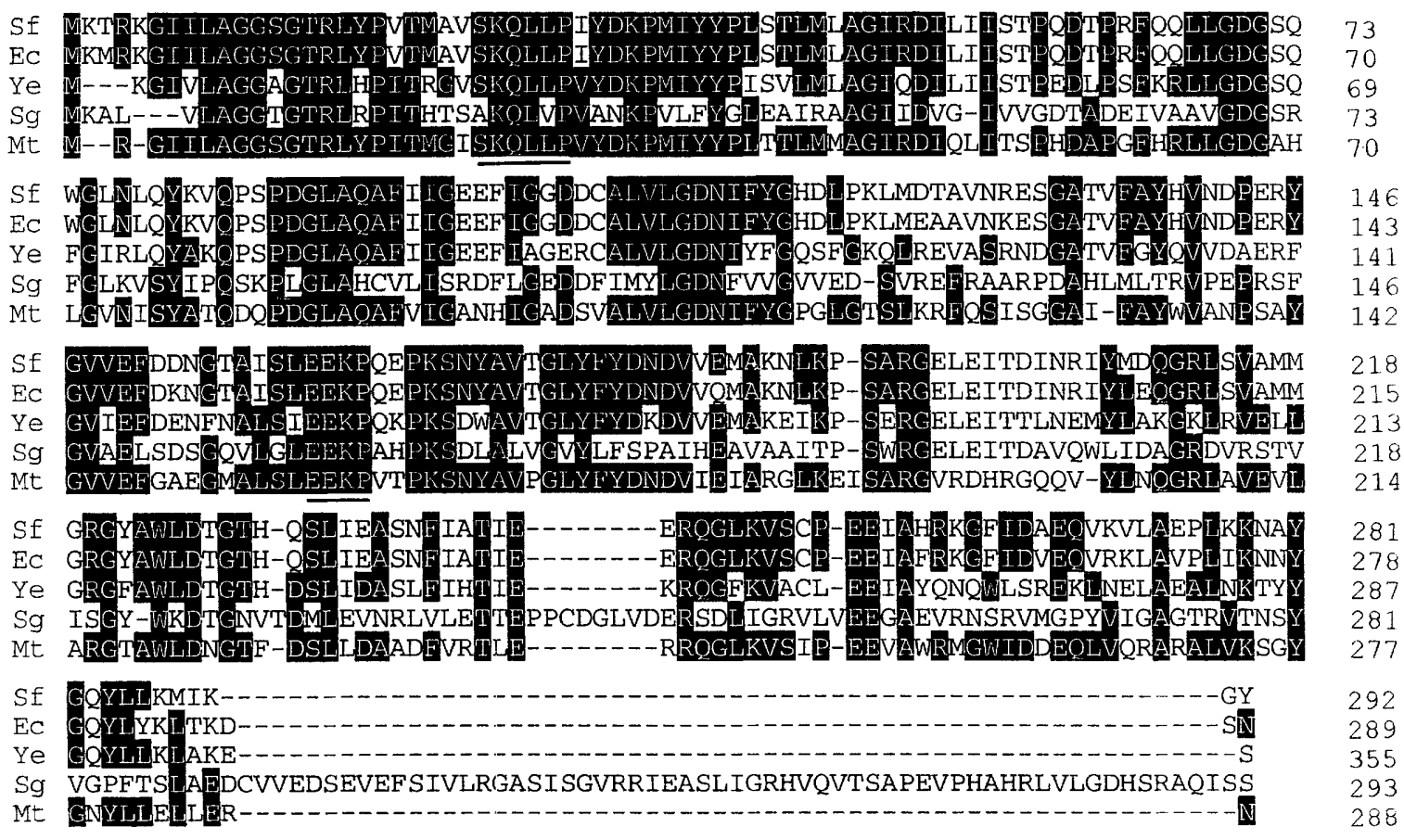

Fig. 7. Comparison of the deduced amino acid sequence for $\alpha$-D-GlC-1-P thymidylyltransferase (RfbA) from $M$. tuberculosis with the amino acid sequence of RfbA from three Gram-negative and one Gram-positive bacteria. The shaded areas are those where the sequence from $M$. tuberculosis is identical to one or more of the other sequences. The conserved putative activator binding site (Thorson et al., 1994; Parsons \& Preiss, 1978) at K-24 ( $M$. tuberculosis) is underlined as is the conserved postulated $\alpha$-Glc-1-P binding site (Thorson et al., 1994) at K-159 (M. tuberculosis). Sf, Sh. flexneri; Ec, E. coli; Ye, Y. enterocolitica; Sg, S. griseus; Mt, M. tuberculosis.

Table 2. Cell-free assays for $\alpha$-D-Glc-1-P thymidylyltransferase and $\alpha$-D-Glc-1-P uridylyltransferase activities in crude extracts of $E$. coli strain $\mathrm{S} \phi 874$ transformed with pYM2 or with the pBluescript $\mathrm{KS}(-)$ vector only

\begin{tabular}{|c|c|c|}
\hline Plasmid & Enzyme & $\begin{array}{l}\text { Activity }\left[\mathrm{nmol} \mathrm{min}^{-1}\right. \\
\left.(\mathrm{mg} \text { protein })^{-1}\right]\end{array}$ \\
\hline pYM2 & $\alpha$-D-Glc-1-P thymidylyltransferase & $20 \cdot 0$ \\
\hline pYM2 & $\alpha$-D-Glc-1-P uridylyltransferase & $74 \cdot 9$ \\
\hline pBluescript II KS $(-)$ & $\alpha$-D-Glc-1-P thymidylyltransferase & $1 \cdot 8$ \\
\hline pBluescript II KS(-) & $\alpha$-D-Glc-1-P uridylyltransferase & 56.9 \\
\hline
\end{tabular}

enzyme dTDP-6-dTal synthase forming the L-talo configuration (Gaugler \& Gabriel, 1973). M. smegmatis utilizes 6-dTal as a component of glycopeptidolipids produced by $M$. smegmatis (McNeil et al., 1989). It should be noted that since $M$. tuberculosis is not known to produce any 6-dTal-containing molecules, dTDP-6dTal synthase is unlikely to be present in $M$. tuberculosis.

The fact that the Southern analysis of various restriction fragments produced from genomic $M$. tuberculosis DNA using a fragment of $r f b A$ as a probe showed only single bands (Fig. 5) suggests that M. tuberculosis has only one copy of $r f b A$. Although the PCR approach described here was successful in amplifying the $r f b A$ gene, similar approaches to amplifying the other three $r f b$ genes were unsuccessful. Also, surprisingly and disappointingly, the remaining $r f b$ genes were not found to be clustered with $r f b A$ as in other bacteria (Minnikin, 1982; Stevenson et al., 1994; Rajakumar et al., 1994). Indeed, although we sequenced approximately $2 \mathrm{~kb}$ on either side of $r f b A$, no sequences with substantial homology to those found in the database were found in these areas. Confirming these results, Dr Tae-Yoon Lee (Yeungnam University, Taegu, Korea), in the context of examining RFLP patterns of various $M$. tuberculosis strains, isolated and sequenced a region of DNA which showed high homology to $r f b B$ and $r f b C$ but not to 
$r f b A$ (Tae-Yoon Lee, personal communication). Several different $30-40 \mathrm{~kb}$ cosmids from the $M$. tuberculosis pGC1 cosmid library containing the DNA sequences homologous to $r f b B$ and $r f b C$ did not hybridize with the $r f b A$ probe (T. Y. Lee, Y. Ma \& M. McNeil, unpublished results) as expected if $r f b A$ is not linked to $r f b B / r f b C$.

The deduced amino acid sequence of the RfbA protein is very similar to that of other bacteria (Fig. 7). Somewhat surprisingly it is more similar to the Gram-negative bacterial proteins (e.g. $59 \%$ identity to the E. coli protein) than to the single Gram-positive $\alpha$-D-Glc-1-P thymidylyltransferase protein sequence ( $32 \%$ identity). However, it should be noted that the $S$. griseus protein is not involved in Rha biosynthesis but rather catalyses the formation of dTDP-Glc as the first step in streptose biosynthesis. The M. tuberculosis $\alpha$-D-Glc-1-P thymidylyltransferase contains the highly conserved lysine at residue 24 (Fig. 7) seen in most, if not all enzymes which transfer a nucleoside phosphate to Glc-1-P (Thorson et al., 1994; Parsons \& Preiss, 1978) and postulated to be part of an activator binding site. It also contains the GluLys-Pro (158-160) sequence which is postulated to be part of the Glc-1-P-binding region (Thorson et al., 1994) and is fully conserved, amongst $\alpha$-D-Glc-1-P nucleoside transferases (Thorson et al., 1994).

Enzymic activity from the cloned RfbA M. tuberculosis protein was readily detected (Table 2) even in the presence of some E. coli background. Although the mechanism of transcription and translation of pYM2 in E. coli was not studied, we assume that the vector lacZ promoter was responsible for transcription and the putative ribosome binding site 6 bases upstream from the $r f b A$ start codon (Fig. 6) was used for translation. E. coli transformed with pYM2 (Table 2) also showed a slight $(1 \cdot 3$-fold $)$ increase in $\alpha$-D-Glc-1-P uridylyltransferase activity. This is not unexpected as $\alpha-\mathrm{D}-\mathrm{Glc}-1-$ $P$ thymidylyltransferase is known to utilize UDP-Glc as a substrate (Bernstein \& Robbins, 1965; Melo \& Glaser, 1965).

$\alpha$-D-Glc-1-P thymidylyltransferase is a potential drug target since it is likely to be an essential protein involved in mycobacterial cell wall linker synthesis and since its enzymic product, dTDP-Glc, is not found in humans. However, care must be exercised targeting this enzyme as potential inhibitors must necessarily not inhibit the very similar $\alpha$-D-Glc-1-P uridylyltransferase needed in human metabolism. It thus remains important to clone the genes for the three remaining dTDP-Rha biosynthetic proteins in mycobacteria as well as the transferase gene which utilizes dTDP-Rha to transfer the Rha residue to the three positions of the linker GlcNAc residue (McNeil et al., 1990; Mikusova et al., 1996) for the purpose of drug targeting.

\section{ACKNOWLEDGEMENTS}

This work was supported by funds provided by Public Health Service grant NIAID, NIH (AI-33706). We gratefully acknowledge the gift of Pep2 from Glenn Songer, the gift of pGC1 from Gerald McDonnel, the construction of the $M$. tuberculosis H37Rv library by David Taylor and the assay for $\mathrm{RfbB}$ by Wenxin Yan. The fundamental and profound contributions of Dr Patrick Brennan to this undertaking are also gratefully acknowledged.

\section{REFERENCES}

Altschul, S. F., Gish, W., Miller, W., Myers, E. W. \& Lipman, D. J. (1990). Basic local alignment search tool. J Mol Biol 215, 403-410.

Bachmann, B. J. (1987). Derivations and genotypes of some mutant derivatives of Escherichia coli K-12. In Escherichia coli and Salmonella typhimurium: Cellular and Molecular Biology, pp. 1190-1219. Edited by F. C. Neidhardt, J. L. Ingraham, K. Brooks Low, B. Magasanik, M. Schaechter \& H. E. Umbarger. Washington, DC; American Society for Microbiology.

Belisle, J. T., Pascopella, L., Inamine, J. M., Brennan, P. J. \& Jacobs, W. R. (1991). Isolation and expression of a gene cluster responsible for the biosynthesis of the glycopeptidolipid antigens of $\mathrm{MycO}$ bacterium avium. J Bacteriol 173, 6991-6997.

Bernstein, R. L. \& Robbins, P.W. (1965). Control aspects of uridine $5^{\prime}$-diphosphate glucose and thymidine $5^{\prime}$-diphosphate glucose synthesis by microbial enzymes. J Biol Chem 240, 391-397.

Brennan, P. J. \& Nikaido, H. (1995). The envelope of mycobacteria. Annu Rev Biochem 64, 29-63.

Daffé, M., McNeil, M. \& Brennan, P. J. (1993). Major structural features of the cell wall arabinogalactans of Mycobacterium, Rhodococcus, and Nocardia spp. Carbohydr Res 249, 383-398.

Deng, L., Mikusova, K., Robuck, K. G., Scherman, M., Brennan, P. J. \& McNeil, M. (1995). Recognition of multiple effects of ethambutol on the metabolism of the mycobacterial cell envelope. Antimicrob Agents Chemother 39, 694-701.

Distler, J., Ebert, A., Mansouri, K., Pissowotzki, K., Stockmann, M. \& Piepersberg, W. (1987). Gene cluster for streptomycin biosynthesis in Streptomyces griseus: nucleotide sequence of three genes and analysis of transcriptional activity. Nucleic Acids Res 15, 8041-8056.

Gaugler, R.W. \& Gabriel, O. (1973). Biological mechanisms involved in the formation of deoxy sugars. VII. Biosynthesis of 6 deoxy-L-talose. J Biol Chem 248, 6041-6049.

Hatfull, G. F. \& Sarkis, G. J. (1993). DNA sequence, structure and gene expression of mycobacteriophage L5: a phage system for mycobacterial genetics. Mol Microbiol 7, 395-405.

McNeil, M. \& Brennan, P. J. (1991). Structure, function, and biogenesis of the cell envelope of mycobacteria in relation to bacterial physiology, pathogenesis, and drug resistance; some thoughts and possibilities arising from recent structural information. Res Microbiol 142, 451-463.

McNeil, M., Chatterjee, D., Hunter, S. W. \& Brennan, P. J. (1989). Mycobacterial glycolipids: isolation, structures, antigenicity, and synthesis of neoantigens. Methods Enzymol 179, 215-242.

McNeil, M., Daffé, M. \& Brennan, P. J. (1990). Evidence for the nature of the link between the arabinogalactan and peptidoglycan components of mycobacterial cell walls. J Biol Chem 265, 18200-18206.

Maniatis, T., Fritsch, E. F. \& Sambrook, J. (1982). Molecular Cloning: a Laboratory Manual. Cold Spring Harbor, NY: Cold Spring Harbor Laboratory.

Marolda, C. L. \& Valvano, M. A. (1995). Genetic analysis of the dTDP-rhamnose biosynthesis region of the Escherichia coli VW187 (O7:K1) $r f b$ gene cluster: identification of functional homologs of $r f b B$ and $r f b A$ in the rff cluster and correct location of the rffE gene. J Bacteriol 177, 5539-5546. 
Melo, A. \& Glaser, L. (1965). The nucleotide specificity and feedback control of thymidine diphosphate-D-glucose pyrophosphorylase. J Biol Chem 240, 398-405.

Mikusova, K., Slayden, R. A., Besra, G. S. \& Brennan, P. J. (1995). Biogenesis of the mycobacterial cell wall and the site of action of ethambutol. Antimicrob Agents Chemother 39, 2484-2489.

Mikusova, K., Mikus, M., Besra, G., Hancock, I. \& Brennan, P. J. (1996). Biosynthesis of the linkage region of the mycobacterial cell wall. J Biol Chem 271, 7820-7828.

Minnikin, D. E. (1982). Lipids: complex lipids, their chemistry, biosynthesis and roles. In The Biology of the Mycobacteria, vol. I, pp. 95-184. Edited by C. Ratledge \& J. L. Stanford, London: Academic Press.

Parsons, T. F. \& Preiss, J. (1978). Biosynthesis of bacterial glycogen : incorporation of pyridoxal phosphate into the allosteric activiator site and an ADP-glucose-protected pyridoxal phosphate binding site of Escherichia coli B ADP-glucose synthase. $J$ Biol Chem 253, 6197-6202.

Radford, A. J. \& Hodgson, A. L. M. (1991). Construction and characterization of a Mycobacterium-Escherichia coli shuttle vector. Plasmid 25, 149-153.

Rajakumar, K., Jost, B. H., Sasakawa, C., Okada, N., Yoshikawa, M. \& Adler, B. (1994). Nucleotide sequence of the rhamnose biosynthetic pathway operon Shigella flexneri 2a and role of lipopolysaccharide in virulence. J Bacteriol 176, 2362-2373.

Shibaev, V. N. (1986). Biosynthesis of bacterial polysaccharide chains composed of repeating units. Adv Carbohydr Chem Biochem 44, 277-339.

Stevenson, G., Neal, B., Liu, D., Hobbs, M., Packer, N. H., Batley, M., Redmond, J. W., Lindquist, L. \& Reeves, P. R. (1994). Structure of the $\mathrm{O}$ antigen of Escherichia coli $\mathrm{K}-12$ and the sequence of its rfb gene cluster. J Bacteriol 176, 4144-4156.

Takayama, K. \& Kilburn, J. O. (1989). Inhibition of synthesis of arabinogalactan by ethambutol in Mycobacterium smegmatis. Antimicrob Agents Chemother 33, 1493-1499.

Takayama, K., Schnoes, H. K., Armstrong, E. L. \& Boyle, R. W. (1975). Site of inhibitory action of isoniazid in the synthesis of mycolic acids in Mycobacterium tuberculosis. J Lipid Res 16, 308-317.

Takayama, K., Armstrong, E. L., Kunugi, K. A. \& Kilburn, J. O. (1979). Inhibition of ethambutol of mycolic acid transfer into the cell wall of Mycobacterium smegmatis. Antimicrob Agents Chemother 16, 240-242.

Thorson, J. S., Kelly, T. M. \& Liu, H. W. (1994). Cloning, sequencing, and overexpression in Escherichia coli of the alpha-Dglucose-1-phosphate cytidylyltransferase gene isolated from Yersinia pseudotuberculosis. J Bacteriol 176, 1840-1849.

Wang, S. F. \& Gabriel, O. (1969). Biological mechanisms involved in the formation of deoxy sugars. V. Isolation and crystallization of thymidine diphosphate-D-glucose oxidoreductase from Escherichia coli B. J Biol Chem 244, 3430-3437.

Zhang, L., al-Hendy, A., Toivan, P. \& Skurnik, M. (1993). Genetic organization and sequence of the $r f b$ gene cluster of Yersinia enterocolitica serotype $\mathrm{O}: 3:$ similarities to the dTDP-L-rhamnose biosynthesis pathway of Salmonella and to the bacterial polysaccharide transport systems. Mol Microbiol 9, 309-321.

Received 24 July 1996; revised 14 October 1996; accepted 17 October 1996. 